Jurnal Ekonomi dan Industri

e-ISSN : 2656-3169

Volume 20, No. 3, September-Desember 2019

p-ISSN : 0853-5248

\title{
PENGARUH MOTIVASI KERJA DAN DISIPLIN KERJA TERHADAP KINERJA KARYAWAN PT. BANK CENTRAL ASIA TBK KCU MATRAMAN
}

\author{
Matheus Alexander Rio ${ }^{1}$ ) \\ 1) Mahasiswa Program Studi Manajemen FE UNKRIS \\ Donny Dharmawan ${ }^{2}$ ) \\ 2) Dosen Program Studi Manajemen FE UNKRIS \\ Alamat: Kampus UNKRIS, Jatiwaringin Jakarta Timur \\ Email : donnydh28@gmail.com
}

\begin{abstract}
This study aims to determine: The effect of work motivation and work discipline on the performance of employees of PT. Bank Central Asia, Tbk KCU Matraman. This research is a causal associative research using a quantitative approach. The subjects of this study were employees at PT. Bank Central Asia, Tbk KCU Matraman as many as 63 employees. Collecting using questionnaires and interviews while data analysis is done using multiple linear regression analysis. The results of the study at a significance level of $5 \%$ indicate that: (1) work motivation has a positive and significant effect on the performance of employees of PT. Bank Central Asia, Tbk KCU Matraman, (2) work discipline has a positive and significant effect on the performance of the employees of PT. Bank Central Asia, Tbk kcu Matraman, (3) work motivation and work discipline have a significant effect on the performance of employees of PT. Bank Central Asia, Tbk KCU Matraman.
\end{abstract}

Keywords: Work motivation, work discipline and performance

\section{PENDAHULUAN}

Manusia diciptakan oleh Tuhan Yang Maha Esa sebagai makhluk sosial. Atas dasar anugerah-Nya sebagai makhluk sosial manusia memiliki sumber kekuatan cipta, rasa, dan karsa yang menjadi karakteristik seseorang sebagai pembeda dari makhluk sosial lainnya. Dengan memiliki sumber kekuatan yang berbeda-beda, manusia adalah suatu sumber daya yang paling utama terhadap organisasi dalam suatu institusi atau perusahaan.

Perusahaan adalah organisasi yang didirikan oleh seseorang atau sekelompok orang atau badan lain yang kegiatannya melakukan produksi dan distribusi guna memenuhi kebutuhan ekonomis manusia. Kegiatan produksi dan distribusi dilakukan dengan menggabungkan berbagai faktor produksi, yaitu manusia, alam dan modal. Kegiatan produksi dan distribusi umumnya dilakukan untuk memperoleh laba.

Keberhasilan dalam suatu perusahaan dipengaruhi oleh dasar kinerja karyawan yang diperoleh dari tingkat pendidikan, kemampuan, dan keahlian yang dimiliki karyawan tersebut, sehingga dapat memberikan kontribusi secara efektif dan efisien kepada perusahaan. Menurut Mangkunegara (2013), Kinerja adalah "hasil kerja yang secara kualitas dan kuantitas yang telah dicapai oleh seorang karyawan atau pegawai dalam mengemban tugasnya sesuai dengan tanggung jawab yang telah diberikan kepadanya". Yang dimaksud dengan kualitas di sini adalah dilihat dari segi kebersihan, kehalusan dan ketelitian dalam menjalankan tugas dan pekerjaan nya. Sedangkan, yang dimaksud dengan kuantitas itu dilihat dari banyaknya jumlah pekerjaan yang harus diselesaikan oleh pegawai atau karyawan tersebut. 
Banyak faktor-faktor yang dapat meningkatkan kinerja karyawan diantaranya adalah motivasi kerja, disiplin kerja, lingkungan kerja, kepemimpinan, budaya kerja, dan lain-lain. Dalam penelitian ini penulis akan meneliti tentang motivasi kerja dan disiplin kerja secara lebih mendalam, sehingga akan menghasilkan penelitian yang baik. Motivasi kerja merupakan daya dorong seseorang karyawan sebagai sumber kekuatan dalam melaksanakan suatu kegiatan untuk mendapatkan hasil yang optimal dalam mencapai tujuan perusahaan. Bahwa sebagai sumber kekuatan motivasi dalam daya dorong seseorang karyawan dipengaruhi oleh kebutuhan yang tidak terpuaskan. Sebagaimana untuk mencapai kebutuhan yang tidak terpuaskan motivasi setiap karyawan memiliki tingkat yang berbeda-beda, di mana semakin tinggi tingkat usaha atas kinerja yang dilakukan seseorang karyawan terhadap suatu kegiatan, maka dapat dinyatakan bahwa semakin tinggi motivasi seseorang karyawan tersebut untuk mencapai tujuan tertentu. Motivasi kerja seseorang karyawan dapat digolongkan secara internal dan secara eksternal. Bahwa secara internal daya dorong seseorang karyawan bersumber dari dalam diri sendiri dan tidak dipengaruhi oleh lingkungan di sekitarnya seperti dengan adanya kebutuhan fisiologis (sandang, pangan dan papan), keinginan untuk berkembang, pengakuan diri, pemahaman akan pekerjaan yang menjadi tanggung jawab, dan pekerjaan yang menantang, sedangkan secara eksternal bahwa daya dorong seseorang karyawan bersumber dari lingkungan kerja seperti dipengaruhi dengan adanya gaji, penghargaan, keselamatan kerja, hubungan antar rekan kerja, kebijakan perusahaan, pendidikan dan latihan kerja.

Sardiman (2014), Pengertian motivasi merupakan "perubahan energi dalam diri seseorang yang ditandai dengan munculnya felling dan didahului dengan tanggapan terhadap adanya tujuan". Selain motivasi yang dapat mempengaruhi kinerja karyawan, salah satu faktor lain yang dapat mempengruhi kinerja karyawan adalah disiplin kerja. Disiplin kerja merupakan peraturan-peraturan yang mengandung norma dan sanksi yang telah ditetapkan oleh perusahaan di mana karyawan memiliki kewajiban untuk menaati peraturan-peraturan secara sukarela. Disiplin kerja memiliki fungsi untuk mengendalikan perilaku seorang karyawan dalam mewujudkan nilai-nilai ketaatan, kepatuhan, kesetiaan, keteraturan dan ketertiban pada suatu perusahaan. Sehingga apabila adanya pelanggaran yang dilakukan oleh karyawan perusahaan seorang manajer atau pimpinan memiliki hak untuk memberikan sanksi dalam mewujudkan kinerja karyawan yang berkualitas untuk mencapai keberhasilan suatu perusahaan dan kinerja karyawan.

Disiplin kerja yang merupakan "sikap mental yang tercermin dalam perbuatan atau tingkah laku individu, kelompok, atau masyarakat berupa ketaatan terhadap peraturanperaturan atau ketentuan yang ditetapkan untuk tujuan tertentu". Apabila semua ketentuan dan aturan diikuti oleh karyawan, maka kinerja akan optimal, atinya suatu sikap menghormati, menghargai, patuh dan taat terhadap peraturan-peraturan yang berlaku, baik yang tertulis maupun tidak tertulis serta sanggup menjalankannya dan tidak mengelak menerima sanksi-sanksinya apabila ia melanggar tugas dan wewenang yang diberikan kepadanya.

PT Bank Central Asia Tbk adalah perusahaan terbuka yang bergerak di bidang perbankan. Bahwa sebagai bank swasta terbesar di Indonesia, PT Bank Central Asia didirikan oleh Sudono Salim pada tanggal 21 Februari 1957 dengan nama Bank Central Asia NV yang merupakan bagian dari Grup Salim. Bahwa kesuksesan PT Bank Central Asia Tbk didukung besar oleh sumber daya manusia yang dimiliki perusahaan. Atas dasar kesuksesannya kantor PT Bank Central Asia Tbk telah tersebar luas diseluruh wilayah Indonesia termasuk PT Bank Central Asia Tbk KCU Matraman yang berada di Jalan Matraman Raya Nomor 14-16 Jakarta Timur. 
Berdasarkan pengamatan penulis terjadi penurun kinerja karyawan, ini dapat dilihat dari tingkat disiplin kerja yang rendah, hal ini dapat mengkibatkan pengaruhnya terhadap layanan pada nasabah. Berikut adalah data absensi kehadiran karyawan PT. Bank BCA KCU Matrman.

\section{Tabel-1}

Absensi Karyawan PT. Bank Central Asia Tbk KCU Matraman” Bulan Januari - April 2019

\begin{tabular}{clccccc}
\hline No & Bulan & \multicolumn{5}{c}{ Karyawan } \\
\hline & & Ijin & Sakit & Terlambat & Absen & Jumlah \\
\hline 1 & Januari & 7 & 3 & 8 & 5 & 23 \\
2 & Pebruari & 5 & 4 & 7 & 3 & 19 \\
3 & Maret & 8 & 3 & 5 & 4 & 20 \\
4 & April & 4 & 2 & 5 & 2 & 13 \\
\hline Total & & & & & & $\mathbf{7 5}$ \\
\hline
\end{tabular}

Sumber: PT. BCA, 2019

Berdasarkan Tabel-1, terlihat bahwa absensi kehadiran karyawan dalam empat bulan terakhir cukup banyak yang tidak datang dalam bekerja, hal ini tentunya akan mengurangi kinerja secara keseluruhan, akibatnya pekerjaan juga ikut terhambat, tugas yang diberikan perusahaan tidak tepat waktu. Sesuai apa yang telah diuraikan di atas maka dapat dinyatakan bahwa keberhasilan dalam suatu perusahaan dipengaruhi oleh kinerja karyawan yang memiliki motivasi kerja dan disiplin kerja. Oleh karena itu, terdapatnya ketertarikan peneliti untuk mengetahui bagaimana perusahaan perbankan swasta Indonesia yaitu PT Bank Central Asia Tbk dalam mengelola sumber daya manusia secara optimal untuk mencapai tujuan dari perusahaan dalam memperoleh keberhasilan.

Tujuan penelitian ini adalah untuk mengetahui pengaruh motivasi kerja dan disiplin kerja terhadap kinerja karyawan PT. Bank Central Asia, Tbk KCU Matraman.

\section{LANDASAN TEORI}

\section{Kinerja}

Siswanto dalam Sandy (2015), menyampaikan kinerja ialah "prestasi yang dicapai oleh seseorang dalam melaksanakan tugas dan pekerjaan yang diberikan kepadanya". Kinerja adalah hasil atau tingkat keberhasilan seseorang secara keseluruhan selama periode tertentu di dalam melaksanakan tugas dibandingkan dengan berbagai kemungkinan seperti standar hasil kerja, target atau sasaran atau kriteria yang telah ditentukan terlebih dahulu dan telah disepakati bersama. Rivai (2005), mengemukakan kata kinerja, jika dilihat dari asal katanya adalah terjemahan dari kata performance yang berasal dari akar kata to perform yang berarti melaksanakan atau menyempurnakan tanggung jawab. Kinerja adalah "hasil atau tingkat keberhasilan seseorang secara keseluruhan selama periode tertentu di dalam melaksanakan tugas dibandingkan dengan berbagai kemungkinan seperti standar hasil kerja, target atau sasaran atau kriteria yang telah ditentukan terlebih dahulu dan telah disepakati bersama". Apabila dalam sebuah kantor tersebut diadakan proyek yang sangat besar, untuk itu diperlukan motivasi dan pengembangan karir yang dapat menunjang kinerja. Proyek yang besar tidak akan berhasil apabila kedua aspek yang menunjang kinerja tersebut tidak dimiliki oleh seorang karyawan. Robbins (2003) dalam Thoyib (2005) mengemukakan bahwa istilah lain dari kinerja adalah "human output yang dapat diukur dari produktivitas, absensi, turnover, citizenship, dan satisfaction".

Werther dan Davis, 1996 dalam Suwatno dan Priansa (2014), penilaian kinerja mempunyai beberapa tujuan dan manfaat bagi perusahaan dan karyawan yang dinilai, 
antara lain : 1). "Performance Improvement. Memungkinkan karyawan dan manager untuk mengambil tindakan yang berhubungan dengan peningkatan kinerja. 2). Compensation Adjustment. Membantu para pengambil keputusan untuk menentukan siapa saja yang berhak menerima kenaikan gaji atau sebaliknya. 3). Placement Decition. Menentukan promosi, transfer dan demotion. 4). Training and Development Needs. Mengevaluasi kebutuhan pelatihan dan pengembangan bagi karyawan agar kinerja mereka lebih optimal. 5). Career Planning and Development. Memandu untuk menentukan jenis karier dan potensi karier yang dapat dicapai. 6). Staffing Process Deficiencies. Mempengaruhi prosedur perekrutan karyawan. 7). Informational Inaccuracies and Job Design Errors. Membantu menjelaskan apa saja kesalahan yang telah terjadi dalam manajemen sumber daya manusia terutama dibidang informasi job-analysis, job design dan sistem informasi manajemen sumber daya manusia. 8). Equal Employment Opportunity. Menunjukkan bahwa placement decision tidak diskriminatif. 9). External Challenges. Kadang-kadang kinerja karyawan dipengaruhi oleh faktor eksternal seperti keluarga, keuangan pribadi, kesehatan, dan lain-lainnya. Biasanya faktor ini tidak terlalu kelihatan, namun dengan melakukan penilaian kinerja, faktor-faktor eksternal ini akan kelihatan sehingga membantu departemen sumber daya manusia untuk memberikan bantuan bagi peningkatan kinerja karyawan. 10). Feedback. Memberikan umpan balik bagi urusan kekaryawanan maupun bagi karyawan itu sendiri”.

Indikator untuk mengukur kinerja karyawan secara individu menurut Robbins, et, al (2015) yaitu: 1). "Kualitas; Kualitas kerja diukur dari persepsi karyawan terhadap kualitas pekerjaan yang dihasilkan serta kesempurnaan tugas terhadap keterampilan dan kemampuan karyawan. 2). Kuantitas; Merupakan jumlah yang dihasilkan dinyatakan dalam istilah seperti jumlah unit, jumlah siklus aktivitas yang diselesaikan. 3). Ketepatan waktu; Merupakan tingkat aktivitas diselesaikan pada awal waktu yang dinyatakan, dilihat dari sudut koordinasi dengan hasil output serta memaksimalkan waktu yang tersedia untuk aktivitas lain. 4). Efektivitas; Merupakan tingkat penggunaan sumber daya organisasi (tenaga, uang, teknologi, bahan baku) dimaksimalkan dengan maksud menaikkan hasil dari setiap unit dalam penggunaan sumber daya. 5). Kemandirian; Merupakan tingkat seorang karyawan yang nantinya akan dapat menjalankan fungsi kerjanya Komitmen kerja. Merupakan suatu tingkat dimana karyawan mempunyai komitmen kerja dengan instansi dan tanggung jawab karyawan terhadap kantor".

\section{Motivasi Kerja}

Hasibuan (2014), mengemukakan motivasi adalah "pemberian daya pengerak yang menciptakan kegairahan kerja seseorang, agar mereka mau bekerja sama, bekerja efektif dan terintegrasi dengan segala daya upayanya untuk mencapai kepuasan". Pada dasarnya sebuah organisasi atau perusahaan bukan saja mengharapkan para karyawannya yang mampu, cakap dan terampil, tetapi yang terpenting mereka mau bekerja giat dan berkeinginan untuk mencapai hasil kerja yang optimal. Oleh karena itu motivasi kerja sangat penting dan dibutuhkan untuk mencapai produktivitas kerja yang tinggi, sehingga tujuan perusahaan dapat tercapai. Manullang (2006), menyampaikan motif sebagai "tenaga pendorong yang mendorong manusia untuk bertindak atau suatu tenaga di dalam diri manusia yang menyebabkan manusia bertindak." Sutrisno (2010), mengatakan motif adalah "daya yang timbul dari dalam diri orang yang mendorong untuk berbuat sesuatu".

Motivasi sebagai proses psikologis dalam diri seseorang akan dipengaruhi oleh beberapa faktor. Sutrisno (2010), mengemukakan faktor-faktor yang mempengaruhi motivasi dapat dibedakan atas faktor internal dan eksternal. 1). "Faktor intern: a). Keinginan untuk hidup. Keinginan ini meliputi memperoleh kompensasi yang 
memadai, pekerjaan yang tetap walaupun penghasilan tidak begitu memadai, dan kondisi kerja yang aman dan nyaman. b). Keinginan untuk dapat memiliki. Keinginan untuk dapat memiliki benda dapat mendorong seseorang untuk mau melakukan pekerjaan. c). Keinginan untuk memperoleh penghargaan. Kemauan seseorang untuk bekerja disebabkan adanya keinginan untuk diakui, dihormati oleh orang lain serta untuk memperoleh status sosial yang lebih tinggi. d). Keinginan untuk memperoleh pengakuan. Keinginan ini meliputi hal-hal adanya penghargaan terhadap prestasinya, dan perusahaan tempat bekerja dihargai oleh masyarakat. e). Keinginan untuk berkuasa. Keinginan untuk berkuasa akan mendorong seseorang untuk bekerja. Kadang-kadang keinginan untuk berkuasa ini dipenuhi dengan cara-cara tidak terpuji, namun cara-cara yang dilakukannya itu masih termasuk bekerja juga. 2). Faktor ekstern: a). Kondisi lingkungan kerja. Lingkungan kerja adalah keseluruhan sarana dan prasarana kerja yang dapat memengaruhi pelaksanaan pekerjaan. b). Kompensasi yang memadai. Merupakan alat motivasi yang paling ampuh bagi perusahaan untuk mendorong para karyawan bekerja dengan baik. c). Supervisi yang baik. Fungsi supervisi dalam suatu pekerjaan adalah memberikan pengarahan, membimbing kerja para karyawan, agar dapat melaksanakan kerja dengan baik tanpa membuat kesalahan. d). Adanya jaminan pekerjaan. Setiap orang akan mau bekerja mengorbankan apa yang ada pada dirinya untuk perusahaan, kalau yang bersangkutan merasa ada jaminan karier yang jelas dalam melakukan pekerjaan. e). Status dan tanggung jawab. Status atau kedudukan dalam jabatan tertentu merupakan dambaan setiap karyawan dalam bekerja. Karyawan pada satu masa juga berharap akan dapat kesempatan menduduki jabatan dalam suatu perusahaan. f). Peraturan yang fleksibel. Bagi perusahaan besar biasanya sudah ditetapkan sistem dan prosedur kerja ini dapat kita sebut dengan peraturan yang berlaku dan bersifat mengatur dan melindungi para karyawan".

\section{Disiplin Kerja}

Disiplin dalam kaitannya dengan pekerjaan adalah ketaatan melaksanakan aturan aturan yang mewajibkan atau diharapkan oleh suatu organisasi agar setiap tenaga kerja dapat melaksanakan aturan-aturan yang mewajibkan atau diharapkan oleh suatu organisasi agar setiap tenaga kerja dapat melaksakan pekerjaan dengan tertib dan lancar. Organisasi juga sangat membutuhkan disiplin kerja, karena dengan mereka merasa sebagai bagian organisasi tersebut maka pegawai berusaha menciptakan suasana kerja yang nyaman bagi dirinya. Hal tersebut sejalan dengan pendapat Martoyo (2011) yang mengemukakan bahwa yang dimaksud dengan disiplin kerja adalah "suatu keadaan yang menunjukkan suasana tertib dan teratur yang dihasilkan oleh orang-orang yang berada dalam naungan sebuah organisasi karena peraturan-peraturan yang berlaku dihormati dan diikuti”.

Sastrohadiwiryo (2003), tujuan pembinaan disiplin kerja para tenaga kerja, antara lain: 1). "Agar para tenaga kerja menaati segala peraturan dan kebijakan ketenagakerjaan maupun peraturan dan kebijakan perusahaan yang berlaku, baik tertulis maupun tidak tertulis, serta melaksanakan perintah manajemen. 2). Dapat melaksanakan pekerjaan dengan sebaik-baiknya serta mampun memberikan pelayanan yang maksimum kepada pihak tertentu yang berkepentingan dengan perusahaan sesuai dengan bidang pekerjaan yang diberikan kepadanya. 3). Dapat menggunakan dan memelihara sarana dan prasarana, barang dan jasa perusahaan dengan sebaik-baiknya. 4). Dapat bertindak dan berprilaku sesuai dengan norma-norma yang berlaku pada perusahaan. 5). Tenaga kerja mampu menghasilkan produktivitas yang tinggi sesuai dengan harapan perusahaan, baik dalam jangka pendek maupun jangka panjang".

Pada dasarnya banyak faktor yang mempengaruhi tingkat kedisiplinan karyawan atau pegawai suatu organisasi seperti yang dikemukakan oleh Hasibuan (2014) sebagai berikut: 
1). "Tujuan dan kemampuan, ikut mempengaruhi tingkat kedisiplinan Pegawai. Tujuan yang harus dicapai harus jelas dan ditetapkan secara ideal serta cukup menantang bagi kemampuan pegawai.Hal ini berarti bahwa pekerjaan yang dibebankan kepada pegawai harus sesuai dengan kemampuan Pegawai bersangkutan, agar dia bekerja sungguh-sungguh dan disiplin dalam mengerjakannya. 2). Teladan pemimpin, sangat berperan dalam menentukan kedisiplinan Pegawai karena pemimpin dijadikan teladan dan panutan oleh bawahannya, pimpinan yang baik harus memberi contoh yang baik, berdisiplin baik, jujur, adil serta, sesuai kata dengan perbuatan. 3). Balas jasa dan kesehjateraan ikut mempengaruhi kedisiplinan pegawai karena akan memberikan kepuasan dan kecintaan pegawai terhadap perusahaan/instansi dan pekerjaannya. Jika kecintaan pegawai semakin baik terhadap pekerjaan maka kedisiplinan mereka akan semakin baik pula. 4). Keadilan, ikut mendorong terwujudnya kedisiplinan pegawai, karena ego dan sifat manusia yang selalu merasa dirinya penting dan minta diperlakukan sama dengan manusia lain. 5). Waskat (Pengaasan melekat), adalah tindakan nyata dan paling efektif dalam mewujudkan kedisiplinan pegawai perusahaan. Waskat efektif merangsang kedisiplinan dan moral kerja pegawai. Pegawai merasa mendapat perhatian, bimbingan, petunjuk, pengarahan, dan pengawasan dari atasannya. 6). Sanksi, berperan penting dalam memelihara kedisiplinan pegawai. Dengan sanksi hukuman, pegawai akan tidak melanggar peraturan-peraturan perusahaan, dan perilaku indisipliner pegawai/karyawan akan berkurang. 7). Ketegasan, pimpinan dalam melakukan tindakan akan mempengaruhi kedisiplinan pegawai perusahaan. Pimpinan harus berani dan tegas, bertindak untuk menghukum setiap pegawai yang indisipliner sesuai dengan sanksi hukuman yang telah ditetapkan".

Manfaat penerapan disiplin kerja baik pada pegawai dalam upaya mencapai disiplin kerja dikemukakan oleh Tohardi (2002) sebagai berikut: 1). "Karyawan akan mendapatkan kepuasan dalam bekerja di organisasi atau perusahaan. 2). Produktivitas organisasi akan berjalan dengan lancar dan sesuai dengan perencanaan. 3). Dengan adanya disiplin yang baik seorang Karyawan dapat menghindari kecelakaan di tempat dia bekerja. 4). Sebagai panutan bagi Karyawan yang bekerja. 5). Tercapainya tujuan dalam organisasi atau perusahaan. 6). Terpelihara citra bagi sebuah organisasi atau perusahaan".

Pada dasarnya banyak indikator yang mempengaruhi tingkat kedisiplinan karyawan suatu perusahaan, diantaranya yang disampaikan oleh Moenir (2014). Indikator - indikator yang mempengaruhi disiplin kerja: 1). "Ketepatan waktu; Ketepatan waktu dalam pekerjaan dan tugas, meliputi: a). Ketepatan waktu dalam melaksanakan tugas. b). Penghematan waktu dalam melaksanakan tugas. 2). Tanggungjawab; Tanggungjawab dalam pekerjaan dan tugas, meliputi: a). Melakukan pekerjaan sesuai dengan rencana. b). Mengevaluasi hasil pekerjaan. c). Keberanian menerima resiko kesalahan. 3). Ketaatan; Ketaatan terhadap peraturan yang telah ditetapkan, meliputi: a). Ketaatan terhadap jam kerja. b). Ketaatan terhadap pimpinan. c). Ketaatan terhadap prosedur dan metode kerja".

\section{METODE PENELITIAN}

Jenis penelitian menggunakan penelitianpenjelasan (explanatory research) dengan pendekatan kuantitatif dan dilakukan di PT Bank Central Asia Tbk KCU Matraman. Penelitian ini menggunakan populasi seluruh karyawan PT. Bank Central Asia KCU Matraman yang berjumlah 63 orang. Teknik sampling yang digunakan adalah sampling jenuh yaitu seluruh karyawan PT Bank Central Asia Tbk KCU Matraman. Metode analisis data dengan analisis deskriptif dan analisis inferensial dengan menggunakan regresi linier sederhana maupun berganda. 


\section{HASIL PENELITIAN DAN PEMBAHASAN}

\section{Analisis Hasil Penelitian}

Tabel-2 Pengaruh Motivasi KerjaTerhadap Kinerja Karyawan PT. Bank Central Asia Tbk KCU Matraman

\begin{tabular}{ccccccc}
\hline \multirow{2}{*}{ Variabel } & \multicolumn{6}{c}{ Parameter } \\
\cline { 2 - 7 } & $\begin{array}{c}\text { Mult. } \\
\mathbf{R}\end{array}$ & $\begin{array}{c}\mathbf{R} \\
\text { Square }\end{array}$ & $\begin{array}{c}\text { Kons } \\
\text { tanta }\end{array}$ & $\begin{array}{c}\text { Coef. } \\
\mathbf{B}\end{array}$ & Sig & $\boldsymbol{\alpha}$ \\
\hline Motivasi & 0.817 & 0.668 & 7.871 & 1.002 & 0.000 & $5 \%$ \\
\hline Pengujian Signifikan & & & & \\
\hline t hitung $>$ t tabel $=\mathbf{1 1 . 0 7 9}>\mathbf{2 . 0 0 0}$
\end{tabular}

Keterangan: Variabel Kinerja

Sumber: data diolah

Persamaan regresi linear sederhana $\mathrm{Y}=7,871+1,002\left(\mathrm{X}_{1}\right)$

Nilai koefisien determinasi $\left(\mathrm{R}^{2}\right)$ sebesar 0.668 , artinya motivasi kerja memberikan kontribusi sebesar 66,8\% terhadap kinerja karyawan PT. Bank Central Asia, Tbk KCU Matraman, sedangkan sisanya sebesar 33,2\% disumbangkan faktor lain.

Berdasarkan Tabel-2, motivasi kerja berpengaruh positif dan signifikan pada tingkat nyata 99\% terhadap kinerja karyawan PT. Bank Central Asia, Tbk KCU Matraman. Koefisien motivasi kerja sebesar 1,002, artinya jika ada peningkatan motivasi kerja satu kali, maka kinerja karyawan PT. Bank Central Asia, Tbk KCU Matraman akan meningkat sebesar 1,002 kali atau sebaliknya. Untuk menguji pengaruh motivasi kerja terhadap kinerja karyawan PT. Bank Central Asia, Tbk KCU Matraman signifikan atau tidak, dilakukan pengujian $t$ hitung dibandingkan dengan $t$ tabel dengan tingkat $\alpha=0,05$, hasilnya adalah $t_{\text {tabel }}=2,000$ yang dilihat dari Tabel distribusi $\mathrm{t}$ (derajat kebebasan $=\mathrm{n}-2 ;(63-2$ =61), dengan uji dua pihak). Berdasarkan perhitungan tersebut dapat dinyatakan bahwa nilai $\mathrm{t}_{\text {hitung }}=11,079$ dan $\mathrm{t}_{\text {tabel }}=2,000$ atau $\mathrm{t}$ hitung $=11,079>\mathrm{t}$ tabel $=2,000$, maka dapat diartikan bahwa motivasi kerja berpengaruh positif dan signifikan terhadap kinerja karyawan PT. Bank Central Asia, Tbk KCU Matraman.

Tabel-3 Pengaruh Disiplin Kerja Terhadap Kinerja Karyawan PT. Bank Central Asia, Tbk KCU Matraman

\begin{tabular}{ccccccc}
\hline \multirow{2}{*}{ Variabel } & \multicolumn{6}{c}{ Parameter } \\
\cline { 2 - 7 } & $\begin{array}{c}\text { Mult. } \\
\mathbf{R}\end{array}$ & $\begin{array}{c}\text { R } \\
\text { Square }\end{array}$ & $\begin{array}{c}\text { Kons } \\
\text { tanta }\end{array}$ & $\begin{array}{c}\text { Coef. } \\
\text { B }\end{array}$ & Sig & $\boldsymbol{\alpha}$ \\
\hline $\begin{array}{c}\text { Disiplin } \\
\text { Kerja }\end{array}$ & 0.734 & 0.539 & 6.184 & 0.932 & 0.000 & $5 \%$ \\
\hline Pengujian Signifikan & & & & & \\
\hline t hitung > t tabel = 11.079 $>\mathbf{2 . 0 0 0}$
\end{tabular}

Keterangan: Variabel Kinerja

Sumber: data diolah

Persamaan regresi linear sederhana $Y=6,184+0,932\left(X_{2}\right)$ 
Nilai koefisien determinasi $\left(\mathrm{R}^{2}\right)$ sebesar 0.539 , artinya disiplin kerja memberikan kontribusi sebesar 53,9\% terhadap kinerja karyawan PT. Bank Central Asia, Tbk KCU Matraman, sedangkan sisanya sebesar 46,1\% disumbangkan faktor lain.

Berdasarkan Tabel-3, disiplin kerja berpengaruh positif dan signifikan pada tingkat nyata 99\% terhadap kinerja karyawan PT. Bank Central Asia, Tbk KCU Matraman. Koefisien disiplin kerja sebesar 0,932, artinya jika ada peningkatan disiplin kerja satu kali, maka kinerja karyawan PT. Bank Central Asia, Tbk KCU Matraman akan meningkat sebesar 0,932 kali atau sebaliknya. Untuk menguji pengaruh disiplin kerja terhadap kinerja karyawan PT. Bank Central Asia, Tbk KCU Matraman signifikan atau tidak, dilakukan pengujian $\mathrm{t}$ hitung dibandingkan dengan $\mathrm{t}$ Tabel dengan tingkat $\alpha=0,05$, hasilnya adalah $\mathrm{t}$ tabel $=2,000$ yang dilihat dari tabel distribusi $\mathrm{t}$ (derajat kebebasan $=\mathrm{n}-2 ;(63-2=61)$, dengan uji dua pihak). Berdasarkan perhitungan tersebut di atas dapat dinyatakan bahwa nilai $\mathrm{t}_{\text {hitung }}=8,451$ dan $\mathrm{t}_{\text {tabel }}=2,000$ atau $\mathrm{t}_{\text {hitung }}=8,451>\mathrm{t}_{\text {table }}=2,000$, dapat diartikan bahwa disiplin kerja berpengaruh positif dan signifikan terhadap kinerja karyawan PT. Bank Central Asia, Tbk KCU Matraman.

\section{Tabel-4 Pengaruh Motivasi Kerja dan Disiplin Kerja Terhadap Kinerja Karyawan PT. Bank Central Asia, Tbk KCU Matraman}

\begin{tabular}{|c|c|c|c|c|c|c|}
\hline \multirow[b]{2}{*}{ Variabel } & \multicolumn{6}{|c|}{ Parameter } \\
\hline & $\begin{array}{c}\text { Mult. } \\
\text { R }\end{array}$ & $\begin{array}{c}\mathbf{R} \\
\text { Square }\end{array}$ & $\begin{array}{l}\text { Kons } \\
\text { tanta }\end{array}$ & $\begin{array}{c}\text { Coef. } \\
\text { B }\end{array}$ & Sig & $\alpha$ \\
\hline Motivasi & \multirow[b]{2}{*}{0.845} & \multirow[b]{2}{*}{0.714} & \multirow[b]{2}{*}{2.459} & 0.733 & \multirow[b]{2}{*}{0.000} & \multirow[b]{2}{*}{$5 \%$} \\
\hline $\begin{array}{c}\text { Disiplin } \\
\text { Kerja }\end{array}$ & & & & 0.388 & & \\
\hline \multicolumn{7}{|c|}{ Pengujian Signifikan } \\
\hline F hitung > I & bel $=7$ & $771>3$ & & & & \\
\hline
\end{tabular}

Keterangan: Variabel Kinerja

Sumber: data diolah

Berdasarkan Tabel-4, Nilai $\mathrm{F}$ hitung sebesar 74,771 jika dibadingkan dengan $\mathrm{F}$ tabel sebesar 3,150 yang didapat dari $(\mathrm{DK}=\mathrm{n}-\mathrm{k}-1 ;=63-2-1=60)$, F hitung lebih besar dari F Tabel $(74,771>3,150)$, artinya secara bersama-sama motivasi kerja dan disiplin kerja berpengaruh positif dan signifikan pada tingkat nyata $99 \%$ terhadap kinerja karyawan PT. Bank Central Asia, Tbk KCU Matraman, atau dengan menggunakan F signifikan yaitu sebesar 0,000 lebih kecil dari tingkat kepercayaan 0,05. Nilai koefisien determinasi $\left(\mathrm{R}^{2}\right)$ sebesar 0.714 , artinya motivasi kerja dan disiplin kerja memberikan kontribusi sebesar 71,4\% kepada kinerja karyawan PT. Bank Central Asia, Tbk KCU Matraman, sedangkan sisanya sebesar $28,6 \%$ disumbangkan faktor lain yang tidak dibahas dalam penelitian ini.

$$
\text { Model Prediksi: } \mathrm{Y}=2,459+0,733\left(\mathrm{X}_{1}\right)+0,388\left(\mathrm{X}_{2}\right)
$$

Berdasarkan Tabel-3, motivasi kerja dan disiplin kerja berpengaruh positif dan signifikan terhadap kinerja karyawan PT. Bank Central Asia, Tbk KCU Matraman, pada tingkat nyata $99 \%$. Koefisien motivasi kerja sebesar 0,733 artinya jika ada peningkatan motivasi kerja satu kali, maka kinerja karyawan PT. Bank Central Asia, Tbk KCU Matraman akan meningkat sebesar 0,733 kali atau sebaliknya dengan asumsi disiplin kerja tidak berubah. Koefisien disiplin kerja sebesar 0,388, artinya jika ada peningkatan disiplin 
kerja satu kali, maka kinerja karyawan PT. Bank Central Asia, Tbk KCU Matraman akan meningkat sebesar 0,388 kali atau sebaliknya, dengan asumsi motivasi kerja tidak berubah.

\section{Pembahasan}

Dari hasil penelitian menunjukkan bahwa adanya peningkatan motivasi kerja diduga akan meningkatkan kinerja karyawan PT. Bank Central Asia, Tbk KCU Matraman. Hal ini dikarenakan pernyataan bahwa gaji karyawan sudah sesuai dengan beban tugas yang diberikan, perusahaan menyediakan fasilitas perumahan bagi karyawan, adanya jaminan sosial tenaga kerja, terdapatnya perlengkapan keselamatan kerja sehingga membuat aman dalam bekerja, adanya pengakuan dan penghargaan atas prestasi kerja, rasa saling menghormati dan menghargai sesama rekan kerja dan juga pada pimpinan, sifat pekerjaan yang menarik membuat karyawan mengeluarkan kemampuannya, dan perusahaan memberika kesempatan pada karyawan untuk mengikuti pelatihan.

Dari hasil penelitian menyatakan bahwa adanya peningkatan disiplin kerja diduga akan meningkatkan kinerja karyawan PT. Bank Central Asia, Tbk KCU Matraman. Hal ini dikarenakan pernyataan bahwa datang lebih awal menambah semangat untuk bekerja, pekerjaan dapat diselesaikan tepat waktu, bekerja seefektif mungkin, pekerjaan dikerjakan sesuai dengan rencana, karyawan diminya mengevaluasi hasil kerjanya, berani menerima risiko atas keslahannya, karyawan datang dan pulang sesuai jam kerja yang ditetapkan, taat terhaap perintah pimpinan dan karyawan mengikuti semua prosedur dan metode kerja.

\section{KESIMPULAN DAN SARAN}

\section{Kesimpulan}

Berdasarkan hasil penelitian dapat disimpulkan sebagai berikut: 1). Motivasi kerja memiliki pengaruh positif dan signifikan terhadap kinerja karyawan PT. Bank Central Asia, Tbk KCU Matraman. Hipotesis pertama diterima. 2). Disiplin kerja memiliki pengaruh positif dan signifikan terhadap kinerja karyawan PT. Bank Central Asia, Tbk KCU Matraman. Hipotesis kedua diterima. 3). Motivasi kerja dan disiplin kerja secara simultan memiliki pengaruh terhadap kinerja karyawan Bank Central Asia, Tbk KCU Matraman. Hipotesis ketiga diterima.

\section{Saran}

Berdasarkan hasil penelitian, berikut ini diberikan beberapa saran antara lain: 1). Bagi pihak PT. BCA, Tbk, KCU Matraman: Diharapkan penelitian ini dapat dijadikan pertimbangan untuk mengatasi masalah yang terjadi pada karyawan. Saran untuk perusahaan antara lain: a). Berdasar hasil penelitian, motivasi kerja masih berada dalam kategori baik. Namun demikian ini dapat dijadikan pertimbangan bagi pihak manajemen perusahaan untuk meningkatkan motivasi karyawan. banyak cara untuk meningkatkan motivasi kerja karyawan diantaranya menambah fasilitas kerja sehingga para karyawan menjadi lebih termotivasi dalam melakukan pekerjaan. b). Berdasarkan hasil penelitian, tingkat disiplin kerja masih berada dalam kategori sedang, perusahaan perlu memerhatikan hal yang menyangkut dengan kedisiplinan dengan menerapkan hukuman atau sanksi bagi karyawan yang melanggar peraturan perusahaan. 2). Bagi peneliti selanjutnya: Diharapkan untuk peneliti selanjutnya dapat mengkaji lebih dalam tentang motivasi kerja dan disiplin kerja yang berpengaruh terhadap kinerja karyawan agar diperoleh gambaran yang lebih lengkap lagi, sehingga diharapkan hasil penelitian yang akan datang lebih baik dari penelitian ini. 


\section{DAFTAR PUSTAKA}

Hasibuan, Malayu S.P. 2014. Manajemen Sumber Daya Manusia. Edisi Revisi. Jakarta: Penerbit PT. Bumi Aksara.

Mangkunegara, A.P. 2013. Manajemen Sumber Daya Manusia Perusahaan.Bandung: Penerbit Remaja Rosda Karya.

Manulang, Marihot. 2006. Manajemen Personalia. Yogyakarta: Gadjah Mada University Press.

Martoyo, Susilo. 2011. Manajemen Sumber Daya Manusia. Yogyakarta: Penerbit BPFE. Yogyakarta.

Mc. Clelland, David. 1997. Management Sumber Daya Manusia. Jakarta: Penerbit Prenhallindo.

Moenir. H.A.S. 2014. Manajemen Pelayanan Umum di Indonesia. Jakarta: Penerbit Bumi Aksara.

Rivai, Veithzal. 2005. Manajemen Sumber Daya Manusia Untuk Perusahaan Dari Teori ke Praktik. Edisi 1. Jakarta: Penerbit PT. Raja Grafindo Persada.

Robbins, Stephen P. 2003. Perilaku Organisasi. Jakarta: Penerbit Index.

Robbins, S.P dan Timothy A. Judge. 2015. Perilaku Organisasi, Edisi 16. Jakarta: Penerbit Salemba Empat.

Sandy Martha, Muhammad. 2015 . "Karakteristik Pekerjaan dan Kinerja Dosen Luar Biasa UIN Sunan Gunung Djati Bandung: Komitmen Organisasi Sebagai Variabel Moderating”. Tesis Magister Universitas Widayatama, Bandung.

Sardiman, A.M,. 2014. Interaksi dan Motivasi Belajar Mengajar. Jakarta: Penerbit Rajawali Pers

Sastrohadiwiryo, Siswanto. B. 2003. Manajemen Tenaga Kerja Indonesia, Pendekatan Administrasi dan Operasional. Jakarta: Penerbit Bumi Aksara.

Sugiyono. 2016. Metodelogi Penelitian Kuantitatif, Kualitatif Dan R\&D. Bandung: Penerbit Alfabeta.

Sutrisno, Edy. 2010. Manajemen Sumber Daya Manusia. Cetakan Ketiga. Jakarta:Kencana Prenada Media Group.

Suwatno dan Priansa, Juni Donni. 2014. Manajemen SDM Dalam Organisasi Publik dan Bisnis. Bandung: Penerbit Alfabeta.

Thoyib, Armanu. 2005. "Hubungan Kepemimpinan, Budaya, Strategi dan Kinerja: Pendekatan Konsep". Jurnal Fakultas Ekonomi Universitas Brawijaya Malang.

Tohardi, Ahmad. 2002. Pemahaman Praktis Manajemen Sumber Daya Manusia, Universitas Tanjung Pura, Bandung: Penerbit Mandar Maju.

Werther, William B. dan Keith Davis. 1996. Manajemen Personalia dan Sumber Daya Manusia. Jakarta: Penerbit Erlangga. 